\section{Kidney \\ Blood Pressure Research}

\title{
Application of Hanging Drop Technique for Kidney Tissue Culture
}

\author{
Shaohui Wang ${ }^{\mathrm{a}} \quad$ Ximing Wang ${ }^{\mathrm{b}} \quad$ Jasmine Boone ${ }^{\mathrm{a}} \quad$ Jin Wie ${ }^{\mathrm{a}} \quad$ Kay-Pong Yip ${ }^{\mathrm{a}}$ \\ Jie Zhang ${ }^{\text {a }}$ Lei Wang ${ }^{\mathrm{a}}$ Ruisheng Liu ${ }^{\mathrm{a}}$
}

aDepartment of Molecular Pharmacology \& Physiology, University of South Florida Morsani College of Medicine, Tampa FL, USA; ${ }^{b}$ Present Address: Shandong Medical Imaging Research Institute, Shandong provincial key laboratory of diagnosis and treatment of cardio-cerebral vascular disease, Shandong University, Jinan, Shandong, China

\section{Key Words}

Hanging drop $•$ Tissue culture $\bullet$ Kidney cortex $\bullet$ Real-time PCR

\begin{abstract}
Background/Aims: The hanging drop technique is a well-established method used in culture of animal tissues. However, this method has not been used in adult kidney tissue culture yet. This study was to explore the feasibility of using this technique for culturing adult kidney cortex to study the time course of RNA viability in the tubules and vasculature, as well as the tissue structural integrity. Methods: In each Petri dish with the plate covered with sterile buffer, a section of mouse renal cortex was cultured within a drop of DMEM culture medium on the inner surface of the lip facing downward. The tissue were then harvested at each specific time points for Real-time PCR analysis and histological studies. Results: The results showed that the mRNA level of most $\mathrm{Na}^{+}$related transporters and cotransporters were stably maintained within 6 hours in culture, and that the mRNA level of most receptors found in the vasculature and glomeruli were stably maintained for up to 9 days in culture. Paraffin sections of the cultured renal cortex indicated that the tubules began to lose tubular integrity after 6 hours, but the glomeruli and vasculatures were still recognizable up to 9 days in culture. Conclusions: We concluded that adult kidney tissue culture by hanging drop method can be used to study gene expressions in vasculature and glomeruli.
\end{abstract}

S. Wang and X. Wang contributed equally to this work and therefore share first authorship. 


\section{Kidney Blood Pressure Research}

\section{Introduction}

The hanging drop technique is a well-established method used in microbiology, which allows the drops of medium to be maintained with minimal evaporation and without spreading. It was initially developed and used for neural tissue culture in the early of 20th century [1-3]. Hanging drop method was firstly used for the study of kidney development using chicken embryos in the 1920s [4]. Hanging drop method has been successfully applied to culture testis tissue [5-8], kidney epithelial cells of proximal tubule [9-11], stem cells [1214], and kidney-like tissues from cultured cells [15]. Recently, handing drop technique has also been used to study developmental regulation during embryogenesis, which offers a three-dimensional (3D) micro-environmental niche to the developing tissue [16].

The hanging drop technique provides a good in vitro system to study developmental regulation during embryogenesis [16]. This method of tissue culture was rapidly adapted to culture different animal tissues [4,17-21]. However, hanging drop method has not been used in adult kidney tissue culture yet.

Monolayer cell cultures of renal epithelial cells are the most common experimental preparations used to study renal functions. Monolayer cell cultures lack 3D structure and tissue-specific functions. It would be a more relevant approach using 3D cell culture in vitro to study the physiology and pathophysiology of renal cells, which allows cells to grow or interact with their surroundings in 3D culture. Stem cells grown in a 3D culture model have proven to be more physiologically relevant in many aspects of cellular functions including viability, proliferation, morphology, differentiation, response to stimuli, migration and invasion, angiogenesis, immune response, drug metabolism, and in vivo relevance [22-27].

Other than handing drop cell culture, simulated microgravity incubators [28] and micro-molded non-adhesive hydrogels $[29,30]$ are the alternative approach to generate 3 -D spheroids. However, the hanging drop methods requires no specialized equipment or reagents and is therefore highly cost-effective. Besides, the simplicity of the method minimizes potential pitfalls [31].

With the increasing interests of translational research, there is a need to study the physiology and pathophysiology in clinically relevant specimen. Tissue culture of renal biopsy samples by hanging drop technique is a very appealing approach to maintain the viability of the tissue because of its simplicity and robustness. To test whether hanging drop culture technique can be used to prepare renal tissue for molecular and biochemical studies, trunks of mouse kidney cortex were kept viable with hanging drop culture technique over a period up to 9 days. The time courses of expression in selected genes related to $\mathrm{Na}$ homeostasis were monitored with real-time PCR at each time points. The structural integrity of renal cortex was determined by histology at the end of each time points. We found that the genes expressed in the vascular and glomeruli were well maintained and stabilized for up to 9 days, but the genes expressed in the tubules were stably maintained for only 6 hours. Correspondingly, the tubules lost cellular integrity after 6 hours in culture.

\section{Materials and Methods}

\section{Animals}

Experiments were conducted on kidney tissue removed from male 12-week-old C57BL/6J mice after euthanization using isoflurane. All procedures and experiments were approved by the Institutional Animal Care and Use Committee at the University of South Florida College of Medicine. All chemicals were purchased from Sigma (St. Louis, MO) except as indicated.

Kidney tissue culture

Adult mouse kidney tissue blocks were cultured in hanging drop medium (DMEM medium, Invitrogen, Carlsbad, CA) containing 0.1mM-MEM non-essential amino acids (NEAA, Invitrogen, Carlsbad, CA), 2mM sodium pyruvate, $2 \mathrm{nM}$ L-glutamine, $0.01 \mathrm{mg} / \mathrm{ml}$ insulin, $5.5 \mu \mathrm{g} / \mathrm{ml}$ transferrin and $5 \mu \mathrm{g} / \mathrm{ml}$ selenium (ITS) supplement, $100 \mathrm{U} / \mathrm{ml}$ penicillin, $100 \mathrm{mg} / \mathrm{ml}$ streptomycin and $10 \%$ fetal bovine serum. To set-up the cultures, $30 \mu \mathrm{l}$ drops of medium were prepared on the lid of a petri dish. Individual tissue pieces (1 mm3) removed 


\section{Kidney Blood Pressure Research}

from the kidney cortex were placed into each drop, and dish was carefully inverted to keep the drops intact with the tissue suspended. PBS was added to the bottom of the dish to prevent dehydration. Tissues were cultured at 37 ${ }^{\circ} \mathrm{C}$ in a humidified atmosphere of $5 \%$ CO2 and 95\% room air for 3, 6, 12, 24, 36,48 hours and 3 , 5, 7, 9 days, respectively. Gene expression analysis from each kidney cortex were triplicated.

\section{Quantitative} real-time PCR (qRTPCR)

qRT-PCR was used to examine the renal cortex gene expression in different time points after the initiation of hanging drop culture. Total RNAs were extracted from renal cortex at different time points according to the manufacturer's instructions. After digestion with RNase-free DNase (Promega, WI, USA) to eliminate the genomic contamination, the cDNAs were synthesized with reverse transcription system using random primer, and used as templates. To evaluate if there is any genomic contamination, a $\beta$-actin primer set (accession numbers of the genes, primer sequences and amplicon sizes are listed in Table 1) amplifying a region including an intron was used. PCR primer sets specific for the $\beta$-actin and related genes were designed using the primer3Plus based on the sequences deposited in the GenBank (accession numbers of the genes, primer sequences and amplicon sizes are listed in Table 1). The housekeeping $\beta$-actin gene was used as the reference for internal standardization. After qualification of the cDNA template, Quantitative PCR analysis was performed using a supermix (iTaq SYRB, Bio-Rad, CA, USA) and Real-Time Detection System (Chromo4, Bio-Rad, CA, USA) according to the manufacturer's protocol. Reaction conditions were set as follows: $95^{\circ} \mathrm{C}$ for $1 \mathrm{~min}$, followed by 40 cycles of $95^{\circ} \mathrm{C}$ for $15 \mathrm{~s}, 60^{\circ} \mathrm{C}$ for $30 \mathrm{~s}$. Reaction of each sample was performed in triplicate. Dissociation analysis was performed at the end of each PCR reaction to confirm the amplificati-
Table 1. Primers

\begin{tabular}{|c|c|c|c|}
\hline Name & $\begin{array}{l}\text { Accession } \\
\text { numbers }\end{array}$ & Primer sequences ( $5^{\prime}$ to $\left.3^{\prime}\right)$ & $\begin{array}{l}\text { Amplicon } \\
\text { sizes }\end{array}$ \\
\hline$\beta$-actin & NM_007393 & 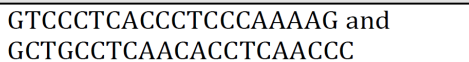 & $266 \mathrm{bp}$ \\
\hline AT1 & NM_177322.3 & $\begin{array}{l}\text { ATCGCTACCTGGCCATTGTC and } \\
\text { GGAAGCCCAGGATGTTCTTG }\end{array}$ & $240 \mathrm{bp}$ \\
\hline AT2 & NM_007429.5 & $\begin{array}{l}\text { TTACCAGCAGCCGTCCTTTT and } \\
\text { GTCAGCCAAGGCCAGATTGA }\end{array}$ & $230 \mathrm{bp}$ \\
\hline ET1 & NM_010104.3 & $\begin{array}{l}\text { TCTTCCAGGTCCAAGCGTTC and } \\
\text { TGCTATTGCTGATGGCCTCC }\end{array}$ & $268 b p$ \\
\hline ETa & NM_010332 & $\begin{array}{l}\text { TTGACCTCCCCATCAACGTG and } \\
\text { AGCACAGAGGTTCAAGACGG }\end{array}$ & $140 \mathrm{bp}$ \\
\hline ETb & NM_001136061 & $\begin{array}{l}\text { CAAGGTCGCTCAGAAAACGC and } \\
\text { CCTAAACAGGCCTCTCGCAA }\end{array}$ & $187 \mathrm{bp}$ \\
\hline A1 & AJ555877 & $\begin{array}{l}\text { CATCCTGGCTCTGCTTGCTA and } \\
\text { CGTTGGCTATCCAGGCTTGT }\end{array}$ & 197bp \\
\hline A2a & NM_009630 & $\begin{array}{l}\text { GCAATTCCGTTGTCAACCCC and } \\
\text { CTCCCATTGGCCCATACTCC }\end{array}$ & $214 \mathrm{bp}$ \\
\hline $\mathrm{A} 2 \mathrm{~b}$ & NM_007413 & $\begin{array}{l}\text { TGCAGCTAGAGACGCAAGAC and } \\
\text { CAAAGGGGATGGCGAAGAGT }\end{array}$ & $189 \mathrm{bp}$ \\
\hline $\mathrm{ENaC} \alpha$ & NM_011324.2 & $\begin{array}{l}\text { CGGGAAACGACCAAACGAAC and } \\
\text { CTTACTCTAGCCCCACCCT }\end{array}$ & $223 \mathrm{bp}$ \\
\hline $\mathrm{ENaC} \beta$ & NM_011325 & $\begin{array}{l}\text { TTGATGAGCGGAACCCTGAC and } \\
\text { GGATTATGCGATCAGGGGCA }\end{array}$ & 276bp \\
\hline $\mathrm{ENaC} \gamma$ & NM_011326 & $\begin{array}{l}\text { CCTGGAGAGAAGATCAAAGCCA and } \\
\text { CCAAGTCAGTCAGGAGGTCAC }\end{array}$ & $346 \mathrm{bp}$ \\
\hline (pro)renin & J00621.1 & $\begin{array}{l}\text { GGTTTCCTCAGCCAGGACTC and } \\
\text { AAAGGCCCATGCCTAGAACC }\end{array}$ & $130 \mathrm{bp}$ \\
\hline $\begin{array}{l}\text { renin/prorenin } \\
\text { receptor }\end{array}$ & AB192471 & $\begin{array}{l}\text { GGACCATTCACCCGACTTGT and } \\
\text { CACTGCGTTCCCACCATAGA }\end{array}$ & 166bp \\
\hline $\mathrm{mK} 13$ & AB016032 & $\begin{array}{l}\text { CCCACAAGATGGCAAAAGCC and } \\
\text { GGCCTCCAGAGTCATCCCTA }\end{array}$ & $163 \mathrm{bp}$ \\
\hline nNOS & NM_008712.3 & $\begin{array}{l}\text { ACTGACACCCTGCACCTGAAGA and } \\
\text { GTGCGGACATCTTCTGACTTCC }\end{array}$ & $113 \mathrm{bp}$ \\
\hline eNOS & NM_008713.4 & $\begin{array}{l}\text { CCTCGAGTAAAGAAATGGGAAGTG } \\
\text { and AACTTCCTTGGAAACACCAGGG }\end{array}$ & $122 \mathrm{bp}$ \\
\hline iNOS & NM_001313922.1 & $\begin{array}{l}\text { CAGCTGGGCTGTACAAACCTT and } \\
\text { CATTGGAAGTGAAGCGATTCG }\end{array}$ & $95 \mathrm{bp}$ \\
\hline ATP1A1 & BC023794 & $\begin{array}{l}\text { TGTGATTCTGGCTGAGAACG and } \\
\text { TCTTGCAGATGACCAAGTCG }\end{array}$ & 206bp \\
\hline NBC & NM_001136260 & $\begin{array}{l}\text { CTGTAGCTGCCAGGCTTTCTGT and } \\
\text { GGGAGAGGGGAACAACCCAAC }\end{array}$ & $217 \mathrm{bp}$ \\
\hline NCC & NM_001205311 & $\begin{array}{l}\text { CCATTGGAAGGAAGGGGAAGTGC and } \\
\text { GTGCGTTCTGACTCTATCCCA }\end{array}$ & $201 \mathrm{bp}$ \\
\hline SGLT2 & NM_133254 & $\begin{array}{l}\text { TCATTGGTGTTGGCTTGTGGTCT and } \\
\text { CATTCCACTCAAATCCAGCCACC }\end{array}$ & $192 \mathrm{bp}$ \\
\hline $\mathrm{Na}-\mathrm{Pi}$ & NM_011392 & $\begin{array}{l}\text { CATCCTACTGTGGTACCCGC and } \\
\text { AAGCACCACAAAGGCCAGTAGA }\end{array}$ & $218 \mathrm{bp}$ \\
\hline NHE1 & NM_016981 & $\begin{array}{l}\text { CCCCAAAGGACAGTAGAGCC and } \\
\text { CCGTCCGCCAAATGGATGGAT }\end{array}$ & $221 b p$ \\
\hline NHE3 & NM_001081060 & $\begin{array}{l}\text { GCCTTCATTCGCTCCCCAAGT and } \\
\text { GAGATGCTTGTACTCCTGCCGA }\end{array}$ & $234 \mathrm{bp}$ \\
\hline NCX1 & NM_001286684 & $\begin{array}{l}\text { CAGCTACCCAGGACCAGTATGC and } \\
\text { ATTGACATTCCGAAGATGGCTCC }\end{array}$ & $252 \mathrm{bp}$ \\
\hline NKCC2 & BC016888 & $\begin{array}{l}\text { GATGCAGAACTGGAAGCAGTCAA and } \\
\text { TCAGACACCAAGGCACAACATTT }\end{array}$ & $269 \mathrm{bp}$ \\
\hline
\end{tabular}




\section{Kidney \\ Blood Pressure Research}

on specificity. After the PCR program, data were analyzed and quantified with the comparative $C_{\mathrm{t}}$ method $\left(2^{-\Delta \Delta} C_{\mathrm{t}}\right)$ based on $C_{\mathrm{t}}$ values for complement genes and $\beta$-actin in order to calculate the relative mRNA expression level.

\section{Histology}

The cultured tissue were harvested and fixed in $4 \%$ paraformaldehyde overnight. Fixed kidney tissues were then processed for paraffin embedding. Tissue sections of $4 \mu \mathrm{m}$ in thickness were then cut, deparaffinilized, and stained with Periodic Acid Schiff (PAS). Images were collected in randomly chosen fields with a $40 \mathrm{x}$ objective lens.

\section{Statistical analysis}

All experiments were performed

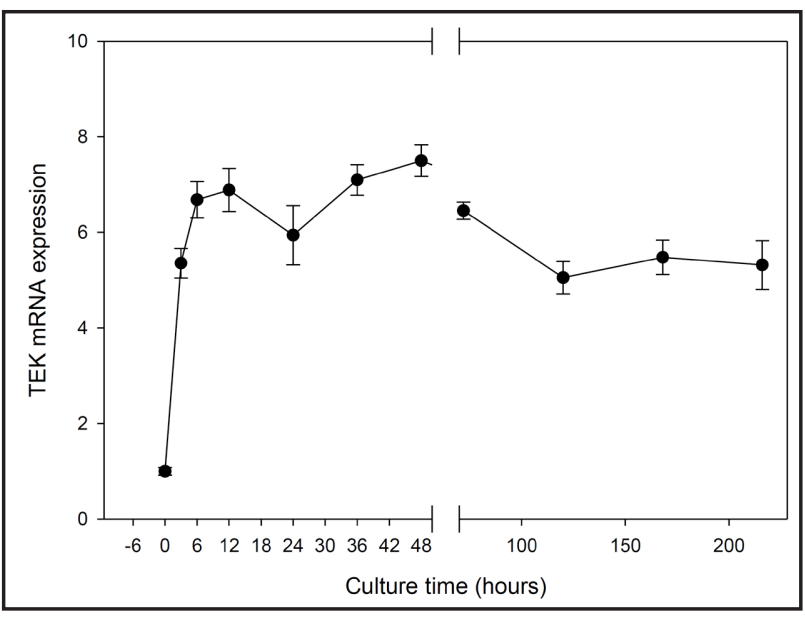

Fig. 1. TEK mRNA expressions in renal vasculature. After 3 hours culture, expressions of TEK was significantly increased, then the genes expression levels were maintained stable for up to 9 days.

in triplicate and repeated three times.

Statistical analysis was performed using SPSS 13.0 for Windows. The data obtained from real-time PCR analysis were subjected to One-way Analysis of Variance (ANOVA) followed by Dunnett 2-sided test to determine differences in the mean values among the treatments and different experiments, and the data were expressed as means \pm SD. Significance was concluded at $p<0.05$.

\section{Results}

Expressions of endothelial marker TEK mRNA in kidney cortex culture

To determine whether the hanging drop culture has any effects on the gene expression in vasculature, we isolated total RNAs for Real-time PCR from the samples cultured for 0 , $3,6,12,24,36,48$ hours and 3, 5, 7, 9 days. TEK (TIE2) is a member of the TIE receptor tyrosine kinase family that is preferentially expressed in vascular endothelial cells [32], we first examined the effects of tissue culture in the TEK mRNA expression. As shown in Fig. 1 , after 3 hours in culture, expressions of TEK was significantly increased and reached the plateau after 6 hours. The levels of TEK expression were maintained stable for up to 9 days.

Expression of genes that are common to both vasculatures and tubules

As shown in Fig. 2, after 3 hours in culture, expressions of Angiotensin II receptor, type 1 (AT1), Angiotensin II receptor, type 2 (AT2), endothelin 1 (ET1), Endothelin receptor type A (ETa), Endothelin receptor type B (ETb), Adenosine A2a receptor (A2a) Adenosine A2b receptor $(\mathrm{A} 2 \mathrm{~b})$ and epithelial sodium channel $(\mathrm{ENaC}) \alpha$ subunit were significantly increased. The genes expression levels were then maintained stable for up to 9 days. Expression level of adenosine A1 receptor (A1) was stable in all time points. Expressions of $\alpha, \beta$ and $\gamma$ subunits of epithelial sodium channel (ENaC) were stable within 24-36 hours of culture. The expression of all ENaC subunits then dropped to less than $10 \%$ of the baseline. On the other hand, the expression of two Na transporters, sodium-calcium exchanger (NCX1) and sodium/hydrogen exchanger 1 (NHE1) remained stable in all measured time points (Fig. 3).

Neuronal nitric oxide synthase (NOS1), inducible nitric oxide synthase (NOS2), endothelial nitric oxide synthase (NOS3), NOS1 $\alpha$ and NOS1 $\beta$ genes expressions were significantly increased in time-dependent manner (Fig. 3). ATPase $\mathrm{Na}+/ \mathrm{K}+$ transporting subunit $\alpha 1$ (ATP1A1) gene expression increased after 3 hours, then decreased after 6 hours and then remained stable until after 24 hours. Further decrease in expression was observed at 36 hours and then remained stable until the last time point of the experiment. 
Fig. 2. (to be continued next page).

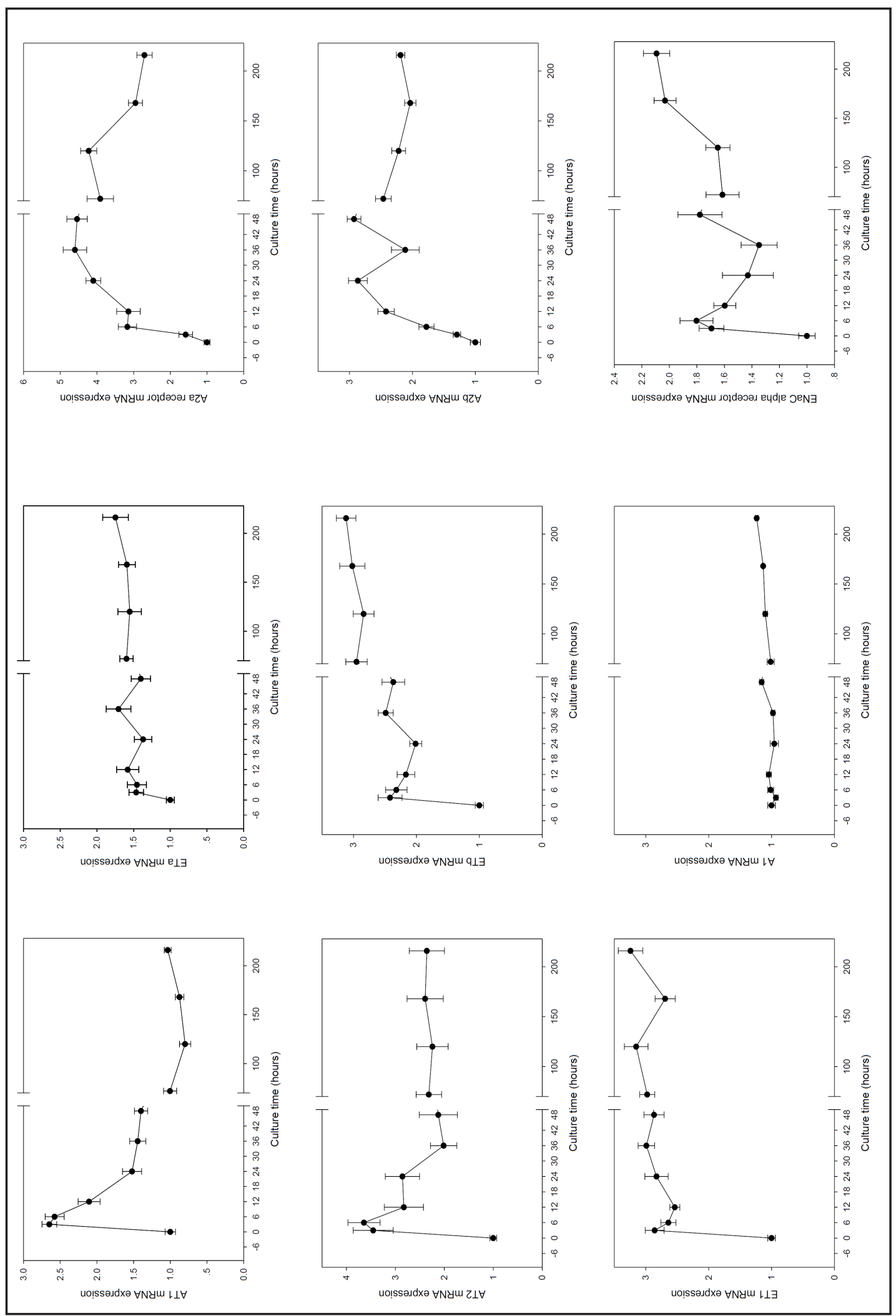




\section{Kidney Blood Pressure Research}

Expression of renin gene was also monitored in cultured renal cortex (Fig. 3). (Pro)renin gene expression maintained stable in all measured time points. Expression level of Renin receptor gene was stable within first 6 hours, decreased after 12 hours, and became undetectable after 3 days in culture. Pro-renin converting enzyme (mk13) gene expression was stable at all measured time points.

The cotransporter sodium-calcium exchanger (NCX1) and sodium/hydrogen exchanger 1 (NHE1) were measured (Fig. 3), NCX1 and NHE1 genes were maintained stable in all measurement times.

Expression of genes that are preferentially expressed in renal tubules

We measured the sodium bicarbonate cotransporter 1 (NBC), Na-Cl cotransporter (NCC), Na-K-Cl cotransporter 2 (NKCC2), sodium/glucose cotransporter 2 (SGLT2), sodium/hydrogen exchanger isoform 3 (NHE3), and sodium/phosphate cotransporter (Na-Pi) genes expression at $0,3,6,12,24,36,48$ hours and 3, 5, 7, 9 days in hanging drop culture. Expressions of NCC, NKCC2, and NHE3 decreased rapidly after the initial three hours in culture (Fig. 4). Interestingly, expression of NBC, SGLT2 and $\mathrm{Na}$-Pi genes increased in the initial 3 hours of culture, then decayed steady.

Time-dependent changes in tubular and vascular morphology

Tissue sections stained with PAS from various time points were shown in Fig. 5. Structural integrity of distal tubules started to deteriorate after 3 hours in hanging drop culture. Deterioration of structural integrity in proximal tubules was found after 6 hours in culture. The glomeruli and vasculature did not show apparent sign of structural deterioration up to 9 days.

\section{Discussion}

The present study demonstrated that hanging drop method can be used for adult kidney tissue culture, but with temporal limitations. Genes expression in renal vasculature and glomeruli can be successfully maintained stable for up to 9 days. However, culture medium needs to be improved for better tubular survival and viability.

The main advantage of the hanging drop cultures is that only a small amount of tissue is required. This is particularly useful in the setting of clinical research, in which the availability of biopsy tissue is limited. In addition, the volume of culture medium required is tiny so that only a small amount of chemical or biological reagents are required to manipulate the environment of the tissue culture. Another important advantage of the hanging drop culture is that all cell types are maintained in a same microenvironment, in which cell-cell 


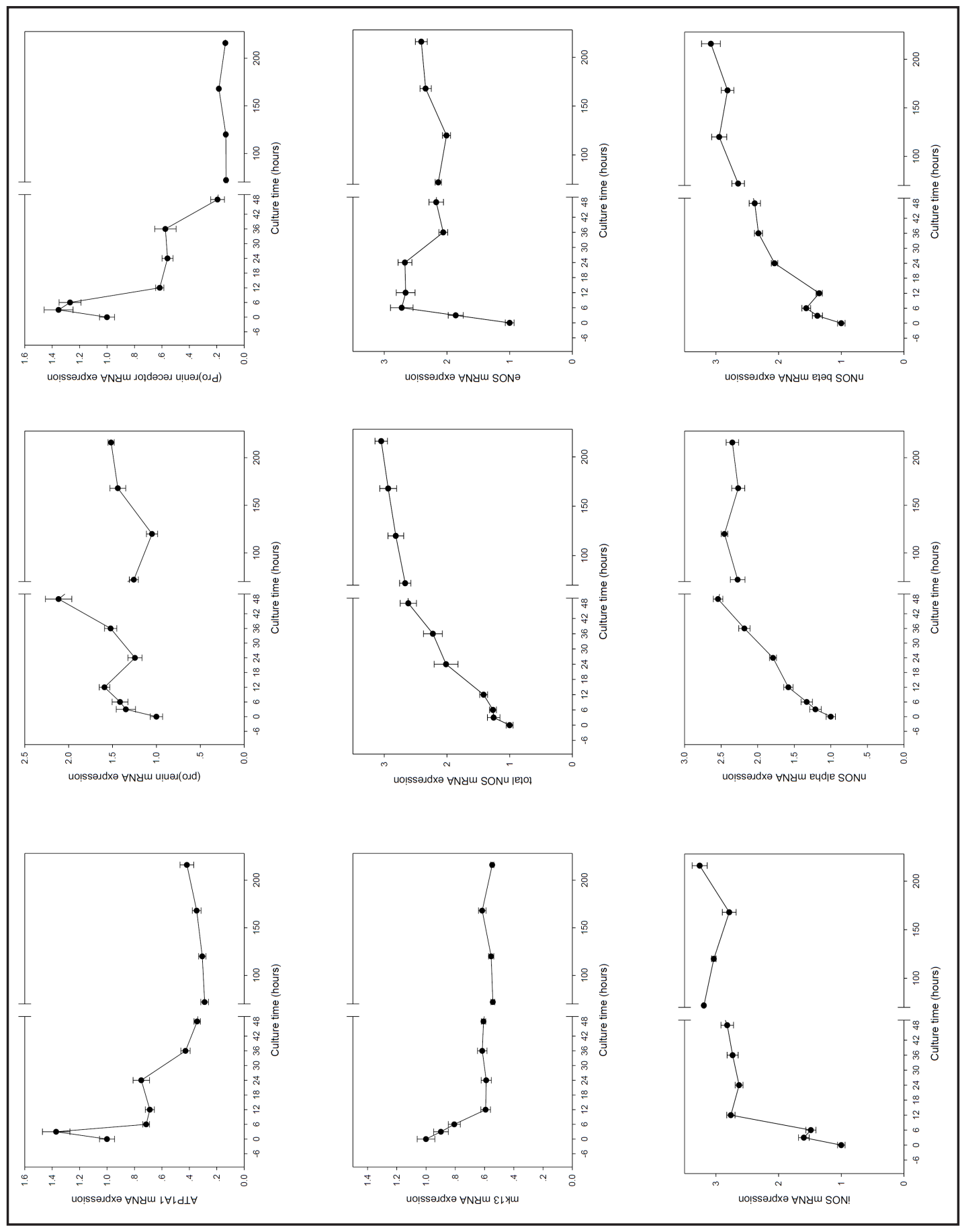

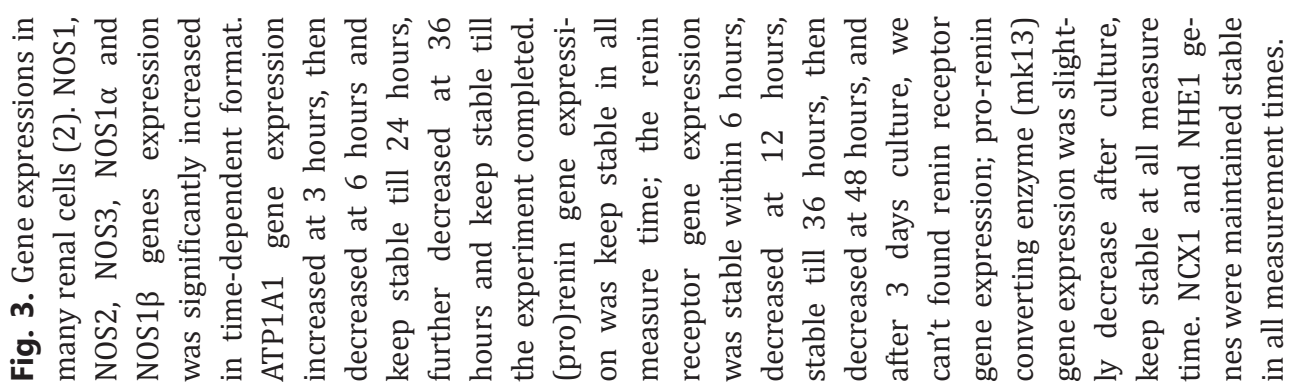




\section{Kidney Blood Pressure Research}

interactions are intact. Hanging drop culture also does not require special equipment or reagents. Its simplicity to simulate the effects of sophisticated 3-D cellular culture is particularly appealing.

Francis firstly applied the hanging drop method to culture chicken embryos and examine the development and growth of the kidney in 1922 [4]. The inferior medial pole of the mesonephros and superior medial pole of the metanephros of the chicken embryos were cultured for 8-10 days and observed the development of vessels, tubules and glomeruli [4]. In the present study, we cultured the adult kidney cortex in the DMEM medium for up to 9 days, then monitored the mRNA stability by Real-time PCR. Among these genes expression that were monitored, some had a large initial increase, gradual increase, gradual decrease or no changes. These changes in expression might be due to the changes in the physical and chemical microenvironment between cells in intact kidney with perfusion and cells in excised renal cortex in culture medium. Cells in excised real cortex did not expose to mechanical force form flow. We did find that multiple mRNA levels reached a new balance after initial alterations.

The endothelial cell-specific receptor tyrosine kinase Tie2 (TEK), which is essential for angiogenesis and vascular stabilization [33], is expressed almost exclusively in endothelial cells in mice, rats, and humans [34,35]. The mRNA level of TEK was increased for the first 6 hours in culture, and then was maintained at high level for up to 9 days. These observations suggested that the genes expression in endothelial cells might remain intact up to 9 days.

The mRNA levels of AT1, AT2, ET1, ETa, ETb, A1, A2a, A2b and ENaC $\alpha, \beta, \gamma$ were maintained at high level after a briefly increased in expression as demonstrated in Fig. 2. The mRNA lever of total NOS1, NOS2, NOS3, NOS1 $\alpha$, NOS1 $\beta$, ATP1A1, (pro)renin, and mk13 were stabilized or slightly increase up to 9 days of culture (Fig. 3). These genes are mainly expressed in vasculatures and glomeruli, indicating the vasculature remained intact. The PAS staining patterns also supported this notion that vasculature and glomeruli were well maintained up to 9 days in culture. Renin receptor mRNA gene expression was decreased after 6 hours in culture, which was different from other genes in Fig. 3. The major site of expression of the (pro)renin receptor in the kidney was the distal renal tubule [36]. It was also identified within the mesangial area of glomeruli [37], and in vascular smooth muscle cells of renal and coronary vessels [34]. Therefore, the decreased expression of (pro)renin receptor was most likely due to the deterioration or degradation in the distal tubules. Unlike most of the other tubular mRNAs, NOS1 expression was quite stable and was in a similar pattern as vascular mRNAs. NOS1 is expressed in the macula densa [38-40], epithelial cells of the distal tubule [41]. Most of the NOS1 in renal cortex is found in the macula densa [38, $40]$. The reason is not clear, may be due to the close contact of the macula densa cells with the glomeruli, which might provide nutrient support to the macula densa cells.

The difficulty to maintain viability of tubular cells might prevent the application of this method to study the long-term tubular functions. Renal tubule is a complex structure composing of many cell types. Each cell type performs unique functions of the kidneys. Therefore, improving the culture medium used to optimize the viability of all the epithelial types of the kidney is essential to successfully adopt this method in the kidney tissue culture. The tubular cotransporter mRNA expressions were decreased after 6 to 12 hours in culture. 

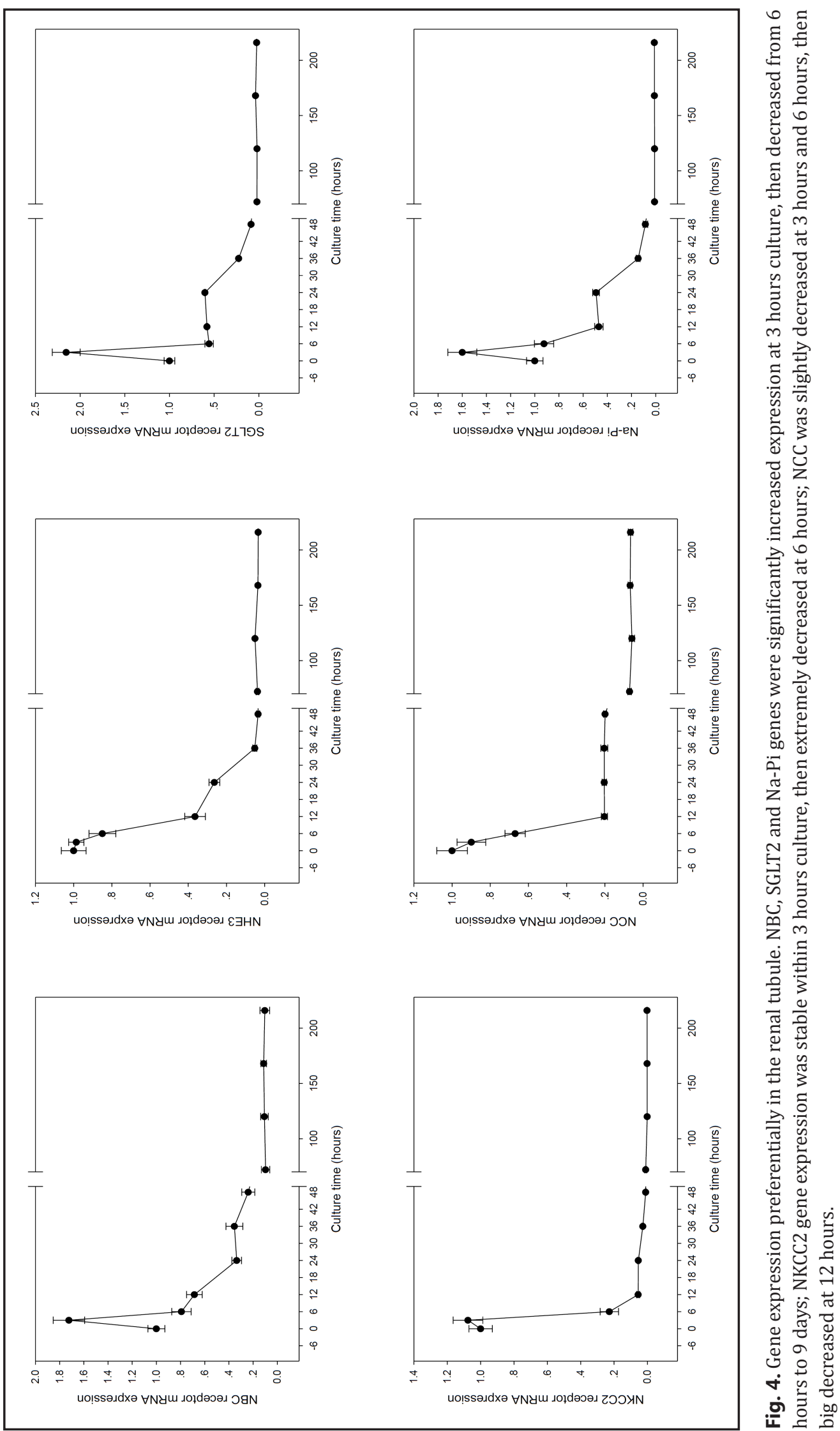


\section{Kidney Blood Pressure Research}

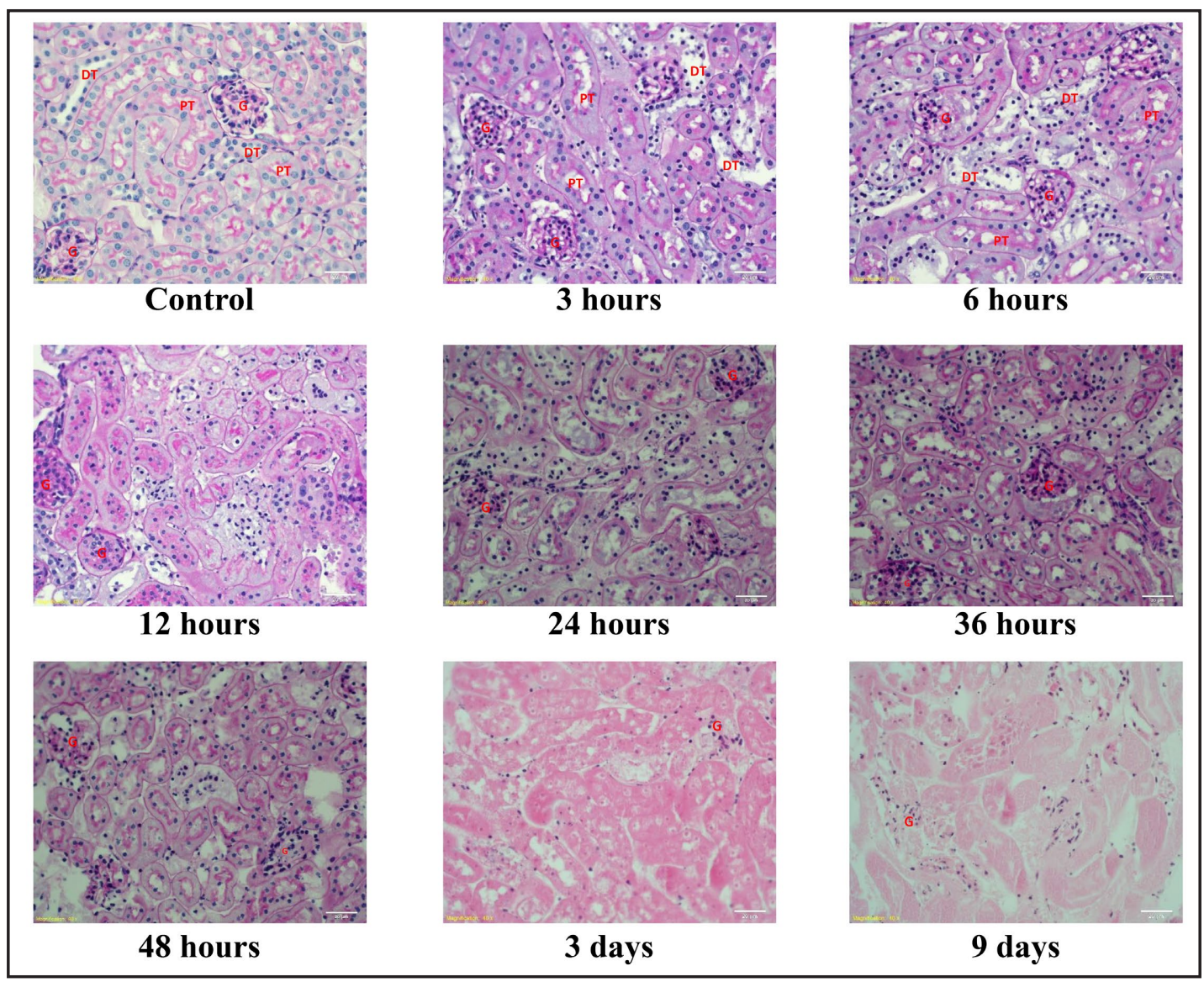

Fig. 5. Morphology and histology of tissue culture. Deterioration in the structural integrity of distal tubule was first observed after 3 hours in culture. Deterioration in proximal tubular structural integrity was found after 6 hours in culture. However, the structure of glomeruli and vasculatures were still well defined after 48 hours in culture. $\mathrm{PT}=$ proximal tubules, $\mathrm{DT}=$ distal tubule, $\mathrm{G}=$ glomeruli, $\mathrm{Bar}=20 \mu \mathrm{m}$.

NBC, NKCC2, NCC, SGLT2 and Na-Pi mRNA expression were all decreased by $30-70 \%$ at 6 hours or 12 hours (Fig. 4). These mRNAs are mainly expressed in the renal tubules. NCX1 and NHE1 mRNA were stably expression up to 9 days (Fig. 3). NCX1 and NHE1 are not only expressed in the tubules. NCX1 is a ubiquitously expressed membrane protein, which is essential for cellular calcium homeostasis in many cells [42]. NHE1 is housing keeping protein and is found in the plasma membrane of virtually all tissues [43]. PAS staining patterns also indicated that the tubular structure in distal tubules and proximal began to compromise after 3 hours and 6 hours in culture, respectively. Therefore, this method with current culture medium was not optimized for functional study of renal tubules.

\section{Conclusion}

The hanging-drop method for adult kidney tissue cultures provides an additional approach for renal research. This method can be used to study gene expressions in kidney vasculature and glomeruli. However, due to the short duration of tubular viability with the current protocol, the application of this method to study tubular function is limited. Future studies are required to improve the culture medium which is capable of maintaining long term viability for all types of cells in the kidney, such as by adding extracellular components 


\section{Kidney Bloód Pressure Research}

and growth factors in the culture medium. Also, the studies on the medullary section of the adult kidney, as well as the kidney tissue in diseased animal models using hanging-drop method could be next candidate for future studies.

\section{Disclosure Statement}

The authors of this manuscript state that they do not have any conflict of interests and nothing to disclose.

\section{Acknowledgements}

This work was supported by National Institutes of Health Grants DK099276 and DK098582 (RL). XW was supported by National Natural Science Foundation of China Grant 81371547, 81571672 and a Taishan Scholar Projection.

\section{References}

1 Blevins SM, Bronze MS: Robert Koch and the 'golden age' of bacteriology. Int J Infect Dis 2010;14:e744-e751.

2 Harrison RG: Observations on the living developing nerve fibers. Proc Soc Exp Biol Med 1907;4:140-143.

3 Koch R: Investigations of the etiology of wound infections (1878). Connecticut: Greenwood Press , 1987.

4 Rienhoff WF: Development and growth of the metanephros or permanent kidney in chick embryos. Johns Hopkins Hosp Bull 1922;33:392-406.

5 Jorgensen A, Young J, Nielsen JE, Joensen UN, Toft BG, Rajpert-De ME, Loveland KL: Hanging drop cultures of human testis and testis cancer samples: a model used to investigate activin treatment effects in a preserved niche. Br J Cancer 2014;110:2604-2614.

-6 Prange JA, Bieri M, Segerer S, Burger C, Kaech A, Moritz W, Devuyst O: Human proximal tubule cells form functional microtissues. Pflugers Arch 2016;468:739-750.

7 Kamiyama M, Garner MK, Farragut KM, Kobori H: The establishment of a primary culture system of proximal tubule segments using specific markers from normal mouse kidneys. Int J Mol Sci 2012;13:50985111.

8 Szczepny A, Hogarth CA, Young J, Loveland KL: Identification of Hedgehog signaling outcomes in mouse testis development using a hanging drop-culture system. Biol Reprod 2009;80:258-263.

- Detrisac CJ, Sens MA, Garvin AJ, Spicer SS, Sens DA: Tissue culture of human kidney epithelial cells of proximal tubule origin. Kidney Int 1984;25:383-390.

-10 Jorgensen A, Nielsen JE, Perlman S, Lundvall L, Mitchell RT, Juul A, Rajpert-De ME: Ex vivo culture of human fetal gonads: manipulation of meiosis signalling by retinoic acid treatment disrupts testis development. Hum Reprod 2015;30:2351-2363.

11 Roulet V, Denis H, Staub C, Le TA, Delaleu B, Satie AP, Patard JJ, Jegou B, Dejucq-Rainsford N: Human testis in organotypic culture: application for basic or clinical research. Hum Reprod 2006;21:1564-1575.

-12 Hodge AJ, Zhong J, Lipke EA: Enhanced stem cell-derived cardiomyocyte differentiation in suspension culture by delivery of nitric oxide using S-nitrosocysteine. Biotechnol Bioeng 2016;113:882-894.

13 Aberdam D: Derivation of keratinocyte progenitor cells and skin formation from embryonic stem cells. Int J Dev Biol 2004;48:203-206.

14 Schmal O, Seifert J, Schaffer TE, Walter CB, Aicher WK, Klein G: Hematopoietic Stem and Progenitor Cell Expansion in Contact with Mesenchymal Stromal Cells in a Hanging Drop Model Uncovers Disadvantages of 3D Culture. Stem Cells Int 2016;2016:4148093.

15 Rosines E, Johkura K, Zhang X, Schmidt HJ, Decambre M, Bush KT, Nigam SK: Constructing kidneylike tissues from cells based on programs for organ development: toward a method of in vitro tissue engineering of the kidney. Tissue Eng Part A 2010;16:2441-2455.

16 Banerjee M, Bhonde RR: Application of hanging drop technique for stem cell differentiation and cytotoxicity studies. Cytotechnology 2006;51:1-5. 


\section{Kidney \\ Blood Pressure Research}

Wang et al.: Hanging Drop for Kidney Tissue Culture

17 Burrows MT: RHYTHMICAL ACTIVITY OF ISOLATED HEART MUSCLE CELLS IN VITRO. Science

1912;36:90-92.

-18 Lewis MR, Lewis WH: MITOCHONDRIA IN TISSUE CULTURE. Science 1914;39:330-333.

19 Roth S, Zhang S, Chiu J, Wirth EK, Schweizer U: Development of a serum-free supplement for primary neuron culture reveals the interplay of selenium and vitamin E in neuronal survival. J Trace Elem Med Biol 2010;24:130-137.

20 van d, V, Brunner D, De SK, Fex SA, Honegger P, Knudsen LE, Lindl T, Noraberg J, Price A, Scarino ML, Gstraunthaler G: Optimization of chemically defined cell culture media--replacing fetal bovine serum in mammalian in vitro methods. Toxicol In Vitro 2010;24:1053-1063.

21 Chen Y, Stevens B, Chang J, Milbrandt J, Barres BA, Hell JW: NS21: re-defined and modified supplement B27 for neuronal cultures. J Neurosci Methods 2008;171:239-247.

22 Langer R, Tirrell DA: Designing materials for biology and medicine. Nature 2004;428:487-492.

23 Lee J, Cuddihy MJ, Kotov NA: Three-dimensional cell culture matrices: state of the art. Tissue Eng Part B Rev 2008;14:61-86.

24 Lin RZ, Chang HY: Recent advances in three-dimensional multicellular spheroid culture for biomedical research. Biotechnol J 2008;3:1172-1184.

25 Abbott A: Cell culture: biology's new dimension. Nature 2003;424:870-872.

-26 Antoni D, Burckel H, Josset E, Noel G: Three-dimensional cell culture: a breakthrough in vivo. Int J Mol Sci 2015;16:5517-5527.

27 Saleh FA, Genever PG: Turning round: multipotent stromal cells, a three-dimensional revolution? Cytotherapy 2011;13:903-912.

28 Marrero B, Messina JL, Heller R: Generation of a tumor spheroid in a microgravity environment as a 3D model of melanoma. In Vitro Cell Dev Biol Anim 2009;45:523-534.

29 Napolitano AP, Dean DM, Man AJ, Youssef J, Ho DN, Rago AP, Lech MP, Morgan JR: Scaffold-free threedimensional cell culture utilizing micromolded nonadhesive hydrogels. Biotechniques 2007;43:494, 496494, 500 .

-30 Tibbitt MW, Anseth KS: Hydrogels as extracellular matrix mimics for 3D cell culture. Biotechnol Bioeng 2009;103:655-663.

31 Foty R: A simple hanging drop cell culture protocol for generation of 3D spheroids. J Vis Exp 2011, DOI $10.3791 / 2720$.

32 Dumont DJ, Yamaguchi TP, Conlon RA, Rossant J, Breitman ML: Tek, a novel tyrosine kinase gene located on mouse chromosome 4, is expressed in endothelial cells and their presumptive precursors. Oncogene 1992; 7:1471-1480.

33 Yamakawa D, Kidoya H, Sakimoto S, Jia W, Naito H, Takakura N: Ligand-independent Tie2 dimers mediate kinase activity stimulated by high dose angiopoietin-1. J Biol Chem 2013;288:12469-12477.

34 Bogdanovic E, Coombs N, Dumont DJ: Oligomerized Tie2 localizes to clathrin-coated pits in response to angiopoietin-1. Histochem Cell Biol 2009;132:225-237.

- 35 Partanen J, Armstrong E, Makela TP, Korhonen J, Sandberg M, Renkonen R, Knuutila S, Huebner K, Alitalo $\mathrm{K}$ : A novel endothelial cell surface receptor tyrosine kinase with extracellular epidermal growth factor homology domains. Mol Cell Biol 1992;12:1698-1707.

-36 Nguyen G: Renin/prorenin receptors. Kidney Int 2006;69:1503-1506.

37 Nguyen G, Delarue F, Burckle C, Bouzhir L, Giller T, Sraer JD: Pivotal role of the renin/prorenin receptor in angiotensin II production and cellular responses to renin. J Clin Invest 2002;109:1417-1427.

-38 Mundel P, Bachmann S, Bader M, Fischer A, Kummer W, Mayer B, Kriz W: Expression of nitric oxide synthase in kidney macula densa cells. Kidney Int 1992;42:1017-1019.

- 39 Sullivan JC, Pardieck JL, Hyndman KA, Pollock JS: Renal NOS activity, expression, and localization in male and female spontaneously hypertensive rats. Am J Physiol Regul Integr Comp Physiol 2010;298:R61-R69.

40 Wilcox CS, Welch WJ, Murad F, Gross SS, Taylor G, Levi R, Schmidt HH: Nitric oxide synthase in macula densa regulates glomerular capillary pressure. Proc Natl Acad Sci USA 1992;89:11993-11997.

-41 Jarry A, Renaudin K, Denis MG, Robard M, Buffin-Meyer B, Karam G, Buzelin F, Paris H, Laboisse CL, Vallette G: Expression of NOS1 and soluble guanylyl cyclase by human kidney epithelial cells: morphological evidence for an autocrine/paracrine action of nitric oxide. Kidney Int 2003;64:170-180.

-42 Schulze DH, Muqhal M, Lederer WJ, Ruknudin AM: Sodium/calcium exchanger (NCX1) macromolecular complex. J Biol Chem 2003;278:28849-28855.

43 Slepkov E, Fliegel L: Structure and function of the NHE1 isoform of the Na+/H+ exchanger. Biochem Cell Biol 2002;80:499-508. 